Discussion Paper No. 12-076

\title{
Decentralizing University Admission - Evidence From a Natural Experiment
}

Julia Horstschräer

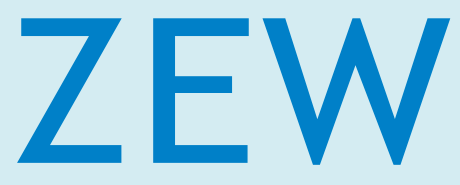

Zentrum für Europäische Wirtschaftsforschung $\mathrm{GmbH}$

Centre for European Economic Research 
Discussion Paper No. 12-076

\title{
Decentralizing University Admission - Evidence From a Natural Experiment
}

\author{
Julia Horstschräer
}

Download this ZEW Discussion Paper from our ftp server:

http://ftp.zew.de/pub/zew-docs/dp/dp12076.pdf

Die Discussion Papers dienen einer möglichst schnellen Verbreitung von neueren Forschungsarbeiten des ZEW. Die Beiträge liegen in alleiniger Verantwortung der Autoren und stellen nicht notwendigerweise die Meinung des ZEW dar.

Discussion Papers are intended to make results of ZEW research promptly available to other economists in order to encourage discussion and suggestions for revisions. The authors are solely responsible for the contents which do not necessarily represent the opinion of the ZEW. 


\section{Non-technical summary}

University admission is organized very differently throughout the world. Prospective students in the U.S. as well as graduate students in the UK need to apply directly at their preferred universities. All undergraduate students in the UK, however, need to apply with the central authority "UCAS" (Universities \& Colleges Admission Service) and merely indicate a preference list of universities. In Germany, the central clearinghouse ('ZVS') allocates students to universities in those subjects which exhibit a shortage of university places. As university admission procedures differ substantially between countries and subjects, it is straightforward to ask: Is the centralized or decentralized procedure better suited to match prospective students to universities?

To answer this question, I exploit the decentralization of university admission in the field of German law studies as a natural experiment. In this subject the centralized admission procedure via the central clearinghouse was replaced by a decentralized procedure in 2002. Using administrative data on all students at German universities and applying a differences-in-differences strategy, the efficiency and quality of the student-university matching is compared between the centralized and the decentralized procedure. My outcome variables measuring matching efficiency and matching quality are (i) the number of first-year students, (ii) the number of unassigned university places, and (iii) the dropout rate.

During the reform process, admission to all law schools except the ones in the largest German federal state of North Rhine-Westphalia was decentralized. Therefore, I use the regional variation over time between law schools in and outside of North Rhine-Westphalia for identification. As a second control group, I employ medical schools because admission to medical schools was centrally administered over the entire observation period. Important to note is that both changes induced by the decentralization process - first, the abolishment of the central clearinghouse and, second, the abolishment of admission restrictions - are considered by my analyses.

The results of my study show that the number of first-year students has increased and the number of unassigned places has decreased after the decentralization. This increase in the matching efficiency is mainly driven by enabling law schools to abolish all admission restrictions. My estimates with respect to the drop-out rates are not significantly affected by the decentralization. Nevertheless, a comparison between the effects for all treated law schools and for the subgroup of law schools which kept admission restrictions suggests that abolishing admission restrictions could be associated with increasing drop-out rates. 


\section{Das Wichtigste in Kürze}

Die Vergabeverfahren von Studienplätzen sind international höchst unterschiedlich ausgestaltet. Zukünftige Studierende in den USA als auch Bewerber um ein Masterstudium in Großbritannien bewerben sich direkt bei ihren präferierten Universitäten. Bachelorstudienplätze in Großbritannien hingegen werden entsprechend der Präferenzlisten der Studenten zentral über die Vergabestelle "UCAS" (University \& Colleges Admission Service) zugeteilt. In Deutschland wiederum ist die Zentralstelle zur Vergabe von Studienplätzen (ZVS, heute: Stiftung für Hochschulzulassung) nur für die Zulassung in Fächern mit knapper Platzzahl zuständig. Aufgrund dieser sehr heterogenen Vergabeverfahren ist es naheliegend zu fragen: Ist die zentrale oder die dezentrale Vergabe von Studienplätzen besser für eine gute Passung zwischen Studenten und Universitäten?

Zur Untersuchung dieser Fragestellung bietet sich die Dezentralisierung der Studienplatzvergabe im Bereich der Rechtswissenschaften als natürliches Experiment an. 2002 wurde für dieses Fach das ZVS Verfahren eingestellt und die Platzvergabe direkt an die Universitäten übertragen. Mit den administrativen Daten der Studentenstatistik und unter Verwendung eines Differenzen-in-Differenzen Ansatzes wird so die Effizienz und Qualität der Passung im zentralen und dezentralen Prozess verglichen. Dafür kommen die Indikatoren (i) Anzahl der Erstsemester, (ii) Anzahl der nichtvergebenen Studienplätze sowie (iii) die Abbrecherrate zum Einsatz.

Die Dezentralisierung der Platzvergabe wurde mit Ausnahme von Nordrhein-Westfalen in allen deutschen Bundesländern umgesetzt. Somit kann die Entwicklung der Passungsindikatoren über die Zeit zwischen den Fakultäten inner- und außerhalb Nordrhein-Westfalens zur Beurteilung der verschiedenen Vergabeverfahren genutzt werden. Als eine zweite Kontrollgruppe zu den rechtswissenschaftlichen Fakultäten werden die medizinischen Fakultäten herangezogen, da für diese der Zugang bis heute zentral über die ZVS geregelt wird. Wichtig ist, dass die Dezentralisierung zum einen die Abschaffung des zentralen Vergabeverfahrens zum anderen aber auch die Abschaffung jeglicher Zugangsbeschränkungen umfassen kann. Die Studie betrachtet daher beide Wirkungskanäle auch separat.

Die Ergebnisse zeigen in Folge der Dezentralisierung eine steigende Zahl an Erstsemestern sowie eine abnehmende Zahl an offenen Studienplätzen in den Rechtswissenschaften. Diese Verbesserung in der Effizienz der Passung ist jedoch vor allem durch die Aufhebung von Zulassungsbeschränkungen getrieben. Die Resultate bezüglich der Abbrecherrate zeigen hingegen keinen signifikanten Effekt auf die Qualität der Passung. Ein Vergleich der Fakultäten mit und ohne Abschaffung der Zulassungsbeschränkungen lässt jedoch vermuten, dass Universitäten, die ihre Zulassungsbeschränkungen fallen gelassen haben, nach der Dezentralisierung eine höhere Abbrecherrate aufweisen. 


\title{
Decentralizing University Admission - Evidence From a Natural Experiment
}

\author{
Julia Horstschräer \\ ZEW, Mannheim *
}

November 8, 2012

\begin{abstract}
Applying a differences-in-differences strategy, I study the decentralization of university admission as a natural experiment. Is the centralized or decentralized procedure better suited to match prospective students to universities? The analysis uses administrative data on all students within Germany and complements the prominent theoretical literature on college admission. The results show that the matching efficiency increased in course of the decentralization. This increase is mainly driven by enabling law schools to abolish admission restrictions. The matching quality is not significantly affected by the decentralization process but suggests that abolishing admission restrictions could be associated with increasing drop-out rates.
\end{abstract}

Keywords: Higher education, college admission problem, university admission

JEL: I21, I23, C21

Acknowledgements: I thank the central clearinghouse ('Zentralstelle zur Vergabe von Studienplätzen, ZVS) and all 16 state ministries of education and research for providing me with the numbers of places per law/medical school. Furthermore, I am grateful to Dr. Simone Wagner (Statistical Office of Bavaria) and Manuel Boos (Statistical Office of Hesse) for their advice and support regarding the administrative student data. For their comments on an earlier version of this paper, I would like to thank my colleagues Melanie Arntz, Grit Muehler, Jens Mohrenweiser and Maresa Sprietsma. This research has been funded by the German Federal Ministry of Education and Research (reference number: 01 JG 0914). Any remaining errors are my own responsibility.

${ }^{*}$ Centre for European Economic Research (ZEW), P.O. Box 103443, D-68034 Mannheim, Germany, E-mail: hortschraeer@zew.de, phone: +49-621-1235196. 


\section{Introduction}

University admission can be either organized by a central clearinghouse or in a decentralized process by the universities themselves. Prospective students in the U.S. as well as graduate students in the UK, for example, apply directly at their preferred universities. All undergraduate students in the UK, however, need to apply with the central authority "UCAS" (Universities \& Colleges Admission Service) and merely indicate a preference list of universities. Historically, decentralized matching procedures were often object to market failure and were therefore replaced by centralized mechanisms. A famous example being the introduction of a central clearinghouse in the early 1950s for the entry-level labor market for American physicians (Roth and Peranson; 1999).

Similarly in Germany, a central clearinghouse ('ZVS') was established in 1973 to admit students in subjects with scarce university places as numbers of applicants were increasing. However, the admission procedure for some subjects - e.g. for law studies in $2002-$ was decentralized again later on. Besides decreasing applications, another reason for this turn was to allow for more competition between universities. Decentralizing university admission comprised two major changes in the admission procedure. First, prospective students apply directly at the universities and are subsequently directly admitted by the universities without the coordination of a central clearinghouse. Second, universities themselves decide on the admission criteria they apply. In fact, some universities abolished all admission restrictions in course of the decentralization, which enabled students to directly enroll into their programs.

In this paper, I exploit the natural experiment of a change from centralized towards decentralized admission to German law schools in order to evaluate the centralized and decentralized matching of students to universities. Using German administrative student data and applying a differences-in-differences strategy, I study the student-university matching with respect to the outcomes (i) the number of first-year students, (ii) the number of unassigned university places, and (iii) the drop-out rates. As admission to all law schools except the ones in the largest German federal state of North RhineWestphalia has been decentralized, I use the regional variation over time between law schools in and outside of North Rhine-Westphalia for identification. In addition, I employ medical schools as a second control group because admission to medical schools has been centrally administered over the entire observation period. Furthermore, my analyses consider both changes induced by the decentralization process the abolishment of the central clearinghouse and of admission restrictions.

On the one hand, a decentralized admission process may be superior to a centralized process as the universities arguably have the most comprehensive information to decide on their student body. On the other hand, decentralized admission may increase uncertainty 
in the process as students need to send out multiple applications and universities need to overbook their places. The decentralized procedure, thus, may lead to (too) late assignment, late enrollment, and unassigned university places (e.g. Roth and Xing; 1994; Müller; 2007, 2009). Furthermore, if universities are overburdened with the admission responsibilities, they may choose the wrong applicants resulting in less human-capital production or higher drop-out rates. Since no admission procedure has been identified as being clearly superior so far, discussions on the optimal university admission process are currently ongoing in Germany as well as on an international level. ${ }^{1}$

The prominent theoretical literature on the "College Admission Problem" (Gale and Shapley; 1962) studies different centralized matching mechanisms (a special set of rules for assigning students to universities) with respect to their matching efficiency. The centralized matching mechanisms are based on preference lists of students over universities as well as on the preferences of universities over students. The literature building upon the seminal paper by Gale and Shapley (1962) identifies two competing mechanisms: the college proposing deferred-acceptance mechanism, which is optimal with respect to the colleges' preferences, and the student proposing deferred-acceptance mechanism, which is student-optimal (Kelso and Crawford; 1982; Roth; 1984a). Within the college (student) proposing version, students (colleges) are able to hold their so far most preferred offer without accepting it right away. Colleges, however, have an incentive to state strategic preferences within the college-optimal mechanism (Roth; 1985). ${ }^{2}$ Within the related field of school choice, Abdulkadiroglu and Sönmez (2003) study the theoretical properties of the "Boston Student Assignment Mechanism". This priority matching mechanism tries to match all students to their school of first choice. However, if a student cannot be assigned at his first school choice, it is unlikely that he is placed at his second preference as all places may already be taken by students who have been placed according to their first choice. Therefore, students and parents strategically decide on the first choice within the Boston matching mechanism. All in all, the theoretical literature on centralized matching mechanisms points out that well-defined matching mechanisms exist but may be sensitive to strategic behavior.

The more recent theoretical literature on decentralized matching is less comprehensive. Roth and Vate $(1990,1991)$ are the first to extend the theoretical college admission literature to decentralized systems by allowing some randomness within the matching process. The literature shows that decentralized systems may produce efficient matchings but also describes situations in which inefficiencies can occur (Roth and Xing; 1994; Pais;

\footnotetext{
${ }^{1}$ See the discussion in the UK on reforming the central admission authority 'UCAS' (UCAS; 2011).

${ }^{2}$ Further evidence on the college admission problem is provided by e.g. Roth (1984b); Roth and Sotomayor (1989); Roth (1991); Kara and Sönmez (1997); Alcalde and Romero-Medina (2005); Klaus and Klijn (2006). For an introduction to the literature see Roth and Sotomayor (1992).
} 
2008b,a; Haeringer and Wooders; 2011). For example, Roth and Xing (1994) report on imperfections that arise due to the timing of transactions within decentralized markets.

Despite the vast theoretical literature on college admission, empirical evidence is very limited. Portela et al. (2008) describe the centralized student allocation process in Portugal and find a mismatch between demand and supply with some universities not being able to fill their places. Related to college admission, Krishna and Ünver (2008) compare two centrally administered matching mechanism for course allocation at an American business school. Using a field and a laboratory experiment, they show that efficiency can be improved by implementing the student proposing deferred-acceptance mechanism. Analyzing a centralized application process to secondary schools, Ajayi (2011) finds that imperfect information about admission chances and differing decision-making skills lead to differences in application behavior. These differences are mitigated by two recent policy reforms, which are examined as natural experiments.

More comprehensive empirical evidence exists within the related field of labor markets, i.e. matching workers to firms. The theoretical literature on centralized matching, for instance, has so far mainly been complemented by experimental and computational economics studying centrally organized entry level labor markets for e.g. new physicians in the US and the UK (e.g. Roth and Peranson; 1999; Kagel and Roth; 2000; Roth; 2002). Empirical studies evaluating the matching efficiency of decentralized labor markets predominantly employ the approach of the matching function, which describes how the stock of unemployed workers and vacancies translate into new matches/hires (see Petrongoli and Pissarides; 2001; Pissarides; 2011, for a survey). Fahr and Sunde (2009), for example, use the variation over time induced by a German labor market reform as a natural experiment to show that the reform has improved the matching efficiency of the labor market.

The German centralized college admission system is empirically analyzed by Braun et al. (2010). They show that the applied matching procedure allows for strategic behavior and moreover penalizes good secondary school graduates, although the mechanism is supposed to be designed in favor of good students. Therefore, the theoretical papers by Westkamp (2010) and Weiler (2009) suggest superior centralized matching algorithms for university admission in Germany. ${ }^{3}$ With respect to decentralized admission in Germany, Müller (2007, 2009) describes frictions induced by the necessity for prospective students to apply at multiple universities. Thus, both the centralized and decentralized admission procedure within Germany exhibit inefficiencies.

This paper contributes to the scarce empirical literature on university admission by evaluating a change from centralized towards decentralized admission as a natural experiment.

\footnotetext{
${ }^{3}$ While Westkamp (2010) suggests a procedure in spirit of Gale and Shapley (1962), Weiler (2009) uses a computational optimization algorithm.
} 
My analyses provide new empirical evidence with respect to the matching efficiency and matching quality of centralized and decentralized admission procedures. To my knowledge, no such empirical evaluation study exists as yet. Roth (2002) suggests that experimental and computational economics can complement the theory on mechanism design. Similarly, I believe that evaluation studies exploiting natural experiments also provide important complementary evidence. Moreover, the theoretical literature may identify inefficiencies in matching procedures, while empirical evaluation studies - similar to Krishna and Ünver (2008) - may also quantify how prevalent inefficiencies are in practice. My analyses are only a first attempt to evaluate different procedures of university admission. More evaluation studies exploiting reforms in college admission procedures are desirable. The extensive empirical literature on the related field of job matching may suggest appealing directions to proceed.

The results of my comparison of centralized and decentralized university admission show that the number of first-year students increased and the number of unassigned places decreased in course of the the decentralization. This suggests a superior matching efficiency within the decentralized procedure. However, considering only a sample of law schools that have kept their admission restrictions, I find no significant changes in these outcomes. Therefore, the decentralization affects the matching efficiency mainly by enabling law schools to abolish all admission restrictions. My estimates with respect to matching quality show no significant changes in the drop-out rates induced by the decentralization. Nevertheless, a comparison between the effects for all treated law schools and for the subgroup of law schools which have always applied admission restrictions suggests that abolishing admission restrictions could be associated with increasing drop-out rates.

The remainder of the paper is structured as follows. In the next section, I give a more detailed overview on the institutional background of the German higher education system as well as on the centralized and decentralized admission procedure (Section 2). Subsequently, Section 4 describes the administrative student data, Section 5 exhibits first descriptive evidence, Section 3 explains the differences-in-differences estimation strategy, and Section 6 presents the results. Section 7 concludes.

\section{Institutional Background}

Contrary to the U.S. higher education system, almost all German universities are publicly funded and administered by one of the 16 German federal states. No tuition fees existed until 2006. Usually, only a registration fee of about 100 Euro had been levied each term by the universities. Therefore, the German higher education system has been considered to be quite homogeneous with respect to university quality. However, competition be- 
tween different institutions has been encouraged by recent reforms. The Bologna Process initiated in 1999 established a new Bachelor and Master degree system throughout Europe in order to create comparable tertiary degrees. This process also aims at increasing the international competitiveness of the European system of higher education. ${ }^{4}$ Furthermore, some German federal states introduced tuition fees from 2006 onwards. As tertiary education used to be free of charge, tuition fees were - and still are - a matter of intense public discussions. Therefore, some federal states which once decided to levy fees today have already abolished them again. ${ }^{5}$ In 2006 and 2007, the German government further ran an excellence competition awarding extra funding to the universities with the best future concept for top-level research. ${ }^{6}$

Along this development towards more competition in the German higher education system, the university admission process has been decentralized for some subjects. Since 1973, the central clearinghouse has allocated university places in subjects for which places were scarce. These subjects included e.g. law and medical studies, biology, psychology, and business administration. As the number of applications were decreasing over time and as students and universities recognized the central clearinghouse mainly as too bureaucratic, some subjects abolished the centralized admission process from 2002 onwards.

In the field of law studies, the student-university matching procedure was decentralized in 2002. The decision to decentralize admission to German law schools was taken very surprisingly in spring 2002. The publication of the central clearinghouse, which was used to inform the applicants of the year 2002, still indicated admission for law studies to be part of the centralized process. However, this information was revised after the decision to decentralize admission has been communicated. The decentralization induced two major changes for the admission to law schools. First, the student-university matching is no longer coordinated by the central clearinghouse. Prospective students after the reform, thus, apply directly at the universities and are subsequently also directly admitted by the universities. Second, universities within the decentralized admission procedure themselves decide on the admission criteria they apply and may also abolish all admission restrictions. The absence of any restrictions enabled prospective students to directly enroll into the law programs of these universities. Hence, the decentralization process can affect the outcome of the matching procedure via two channels: the abolishment of the central coordination by the clearinghouse and the annulment of admission restrictions.

Important for my estimation strategy is that admission to law schools has not been decentralized within the largest German federal state of North Rhine-Westphalia. As the central clearinghouse is located within the federal state of North Rhine-Westphalia

\footnotetext{
${ }^{4}$ For an evaluation of the German Bologna Process see Horstschräer and Sprietsma (2010).

${ }^{5}$ For analyses regarding the introduction of tuition fees in Germany see Dwenger et al. (2012) and Hübner (2009).

${ }^{6}$ For an evaluation of the excellence initiative see Horstschräer (2011).
} 
and as North Rhine-Westphalian universities were also excluded from other nationwide decentralization processes, this decision most likely was politically motivated. The central clearinghouse, therefore, has been administering admission to law schools within North Rhine-Westphalia also after the reform of 2002. As admission has been decentralized in the other federal states, prospective students could apply directly at the schools outside of North Rhine-Westphalia and simultaneously also for the centralized process within North Rhine-Westphalia.

Before comparing the different matching procedures, let me explain the German centralized matching procedure in more detail. Centralized admission in Germany consists of two separate steps. In a first step, the prospective students are selected for e.g. law studies, and in a second step, they are allocated to universities. In the first step, the central clearinghouse selected students by three different procedures, which are:

- Procedure $G$ : Admission according to the final secondary school grade.

- Procedure $W$ : Admission according to the time applicants have already been waiting for admission.

- Procedure $U$ : Admission according to criteria set by the universities. ${ }^{7}$

These three procedures are applied sequentially. First, all university places that are supposed to be filled by procedure $G$ are assigned, second, procedure $W$ is applied, and last in row is procedure $U$. The amount of places to be filled by each procedure has been fixed in advance. In 2000 for example, $55 \%$ of the overall available university places were assigned by the secondary school grade $(G), 25 \%$ by the time of waiting $(W)$ and $20 \%$ by the universities' criteria $(U)$. Due to political discussion and the public debate on the drawbacks of the central clearinghouse, procedure $U$ has become more important over time. Until 1999, students have only been selected with respect to their grade and their waiting time, while, since 2005, 60\% of the places are filled according to the universities' criteria. Within procedure $U$, many universities, however, relied on the secondary school grade as their only selection criteria (ZVS; 2000). Therefore, the influence universities gained within the centralized admission process has been limited. Furthermore, the change in the centralized procedure is only relevant for the subjects remaining nationwide centrally administered after 2002 - e.g. medical studies. Within the centralized admission process for law schools located in North Rhine-Westphalia only procedure $G$ and $W$ have been applied again after the reform of 2002 . The selection criteria for these schools, thus, have not changed severely over time.

While prospective students in procedure $U$ are selected and allocated in one step, students selected within procedure $G$ and $W$ are allocated to universities in a separate second

\footnotetext{
${ }^{7}$ In fact, universities decide on the basis of the following admission criteria: (i) the final secondary school grade, (ii) interviews with the applicants, (iii) the previous working experience, or (iv) a combination of these three.
} 
step. Prospective students in these two procedures are mainly allocated according to their stated first university preference. In case more students indicated a university as their first preference than this university offered places, the secondary school grade or social criteria ${ }^{8}$ are used for tie-breaking. If a selected student cannot be matched to his first choice, the central clearing house similarly tries to assign a place at the school of second preference. However, all applicants who listed this college as their first preference are placed at this college first. The tie-breaking rules for colleges changed several times within the observation period, but the indicated first university preference has always been most important for the allocation of prospective students in procedure $G$ and $W$.

In order to relate the German admission procedure to the theoretical literature on college admission, I can describe the second step of the centralized procedure, i.e. the allocation of prospective students to universities, more formally. The allocation mechanism within procedures $G$ and $W$ assigns students as follows:

- Step 1: For each university, consider the students who indicated the according university as their first preference. Subsequently, assign the university places among them according to their final secondary school grade (social criteria) until all students are assigned at their first preference or no places remain.

- Step k: For each university with unassigned places, consider the students who indicated the according university as their $k$ th preference. Subsequently, assign the university places among them according to their final secondary school grade (social criteria) until all students are assigned at their $k$ th preference or no places remain.

This procedure corresponds to the prominent "Boston Student Assignment Mechanism" studied within the theoretical literature on school choice. The Boston priority-matching mechanism has been shown to produce stable outcomes, i.e. a situation in which neither a student nor a college prefer one another compared to their assignment. However, the mechanism gives an incentive for strategic preference lists as prospective students may not state their true preference but choose a school as their first choice at which they have realistic chances to be admitted (Abdulkadiroglu and Sönmez; 2003).

The matching mechanism within procedure $U$ corresponds to the college proposing deferredacceptance mechanism. Within the matching process, the universities with $q_{u}$ places admit the $q_{u}$ students who rank highest with respect to the universities' preferences. Each student subsequently accepts his highest-ranked offer and rejects all others. In turn, the universities offer the places which remain unassigned after the first round to the highestranked applicants who have not yet accepted an offer and who have not yet received an offer by the according university. Again, students only accept the highest-ranked offer. This algorithm stops when all students are assigned or when no places remain to be

\footnotetext{
${ }^{8}$ E.g. severe disabilities, spouse/child living close to the university, proximity to a student's hometown if registered at the parents home.
} 
allocated. The outcome of the college proposing deferred-acceptance mechanism is the stable matching most preferred by colleges and least preferred by students (Roth; 1984a). Furthermore, Roth (1985) shows that no college-optimal deferred-acceptance mechanism exists, which makes it a dominant strategy for all colleges to state their true preferences.

Within the decentralized admission process, all students apply directly at the universities. Students usually apply for multiple universities at the same time because they have imperfect information about their chances to receive an offer. At the same time, universities make more offers than their actual capacity as they must expect some students to reject their offer. The consequences of this procedure may be e.g. (too) late assignment, late enrollment, and unassigned university places (e.g. Roth and Xing; 1994; Müller; 2007, 2009). Furthermore, if universities are overburdened with the new admission responsibilities, they may choose the wrong applicants resulting in less human-capital production or higher drop-out rates.

All in all, the theoretical evidence with respect to centralized and decentralized university admission in Germany points at possible inefficiencies in both systems. Therefore, an empirical comparison of centralized and decentralized admission procedures may provide important insights in how these inefficiencies affect the student-university matching in practice.

\section{Estimation Strategy}

For comparing the matching efficiency and the matching quality of the centralized and decentralized university admission procedure, I exploit the abolishment of the centralized admission in the field of law as a natural experiment. The applied differencesin-differences approach does not only compare the matching efficiency and quality for admission before and after the reform, but it also compares the development over time to a control group of university departments which have not experienced any change in university admission.

The decentralization of university admission in the field of law offers a setting which is very well suited for differences-in-differences estimation. As the German federal state of North Rhine-Westphalia - unlike all other federal states - has not decentralized admission to law schools in 2002, the six law schools of this state form a natural control group. This allows me to compare the development in the matching efficiency and quality over time for the treated law schools outside of North Rhine-Westphalia with the control law schools within North Rhine-Westphalia. The decision of North Rhine-Westphalia not to decentralize admission to law schools has been taken independently of the situation at North Rhine-Westphalian law schools. As the central clearinghouse is located within 
North Rhine-Westphalia and as also other subjects have not been decentralized in North Rhine-Westphalia, it was rather a political motive that drove this decision. Using the regional variation between federal states for identification has the advantage that I can compare schools within the same subject. Thus, differences between subjects, e.g. a different student body, do not influence my results. However, regional differences and changes in the composition of treatment and control group, i.e. prospective students now applying for law studies outside of North Rhine-Westphalia because admission has been decentralized, may affect the results of this comparison.

Therefore, I consider medical schools outside of North Rhine-Westphalia as an additional, second control group. Admission to medical schools was organized centrally over the entire observation period and thus was unaffected by the decentralization process in the field of law studies. For this second control group, it is less likely that the composition of treatment and control group changes as treatment and control group differ in subject. Furthermore, university departments of the treatment and control group in this comparison are located within the same geographical region. Thus, regional differences do not influence the estimations employing the second control group. Differing trends between both subjects over time, however, may affect this alternative differences-in-differences approach. Therefore, my estimations account for differing time trends.

Being able to apply a differences-in-differences analysis with two alternative control groups is an advantage because both approaches complement each other and therefore increase the reliability of my estimation strategy. The formal representation of the classical differences-in-differences analysis for both alternative control groups reads as follows:

$$
y_{i t}=\alpha_{1} \text { LAWtreated }_{i} \times \text { AFTER }_{t}+\alpha_{2} \text { LAWtreated }_{i}+\alpha_{3} \text { AFTER }_{t}+\alpha_{4} X_{i t}+\epsilon_{i t}
$$

The outcome $y_{i t}$ for university department $i$ in year $t$ represents the outcome variables (i) the number of matriculated students, (ii) the number of unassigned university places and (iii) the share of drop-outs. These measures of matching efficiency and matching quality are described in more detail in Section 4. The classical differences-in-differences approach includes as explanatory variables a binary variable indicating the treated law schools LAWtreated $_{i}$ for which university admission has been decentralized, a binary variable indicating the years after the decentralization $A F T E R_{t}$, and the interaction between these two variables $L A W$ treated $_{i} \times A F T E R_{t}$, which coefficient represents the effect of interest. The classical approach, thus, controls for differences between treated schools and control schools and for differences over time before and after the decentralization of university admission in the field of law studies. The interaction of interest - i.e. the effect of decentralizing university admission - thus only picks up changes in matching 
efficiency and matching quality after the reform which are not simultaneously observed in the control group.

Furthermore, I include additional covariates $X_{i t}$ to control for the introduction of tuition fees from 2006 onwards and for the introduction of an excellence status for some universities within an excellence competition run by the German Government. ${ }^{9}$ The covariates also include separate time trends for the treated schools and the control schools by interacting a binary variable indicating the treated schools and control schools respectively with a continuous variable for all years of observation. These interactions account for linear time trends in the treated schools and the control schools before the reform and therefore avoid a bias in the estimates merely driven by differing time trends. The descriptive evidence (Figures 2 - 4) suggests that especially subject-specific time trends may be important for the comparison with medical schools. Using a continuous year variable assumes linear time trends. This assumption is justifiable as the matching quality indicators indeed seem to develop approximately linear before the decentralization in 2002 .

An alternative estimation approach exploits the panel structure of the data by accounting for university department fixed effects. With this approach, the estimation merely relies on the variation over time on the level of university departments. Everything that is constant over time for a specific law or medical school is netted out. Thus, adding the fixed effect to the estimation equation allows a more precise analysis by estimating the following equation:

$$
y_{i t}=\beta_{1} \text { LAWtreated }_{i} \times A F T E R_{t}+\beta_{2} A F T E R_{t}+\beta_{3} X_{i t}+v_{i t}+\epsilon_{i t}
$$

The effect of interest is again the coefficient of the interaction LAWtreated $_{i} \times A F T E R_{t}$ which estimates the effect of decentralizing university admission on the outcomes $y_{i t}$ representing matching efficiency and matching quality. In this specification, the fixed effect $v_{i t}$ captures all school-specific and time-constant variation in matching efficiency and quality. Therefore, the time-constant indicator variable LAWtreated $_{i}$ is not identifiable - in other words not necessary - and is thus dropped. All other covariates are the same as in Equation 1. The standard errors are clustered by university departments.

The decentralization of university admission for law studies in 2002 is a suitable natural experiment in university admission for several reasons. First, it offers two appropriate control groups to identify the effect of decentralizing university admission. Second, it allows me to disentangle the change in university admission from the European Bologna Process introducing a new (Bachelor and Master) degree system throughout Europe.

\footnotetext{
${ }^{9}$ For a more detailed analysis of the excellence competition see Horstschräer (2011).
} 
Until this day, the degree system in law and medical studies remains unaffected by the Bologna Process. As a certain quality standard of law and medical graduates is of public interest, the final degree in both subjects has always been a centralized national exam. Third, the decentralization in law studies was already implemented in 2002, which offers the opportunity to observe five post-treatment years that are not affected by the introduction of tuition fees in some federal states. Fourth, the same timing argument applies for the excellence competition carried out by the German government in 2006 and 2007. Hence, the natural experiment in university admission for law studies allows me to identify the isolated effect of a change from a centralized towards a decentralized admission procedure.

\section{Data}

For the evaluation of the change from a centralized towards a decentralized university admission, I use administrative student data comprising individual information on all matriculated students in Germany over the years 1995 to 2008. The data set is provided by the statistical offices of Germany and relies on the registration data reported by each German university. ${ }^{10}$ The advantage of the administrative student data is that I can observe all students in Germany over a long period of time. The data set contains detailed information on the course of studies and a limited number of student background variables.

The outcome measures I use to evaluate the decentralization of university admission aim at assessing the matching efficiency and the matching quality of the admission procedure. Matching efficiency in this context means the quantitative outcome of the admission process, e.g. the number of students that are matched to a university. This aspect is important as it may reveal that the admission procedure yields an inefficient use of resources, which might be the case if not all supplied university places can be filled. The matching quality additionally evaluates whether students are assigned at universities that fit them with respect to e.g. their preferences or ability. The outcome measures I use to proxy matching efficiency and matching quality are:

1. The number of first-year students

2. The number of unassigned university places

3. The drop-out rate

\footnotetext{
${ }^{10}$ Statistical Office Germany, Higher Education Statistics.
} 
The number of first-year students assesses the matching efficiency of the student-university matching, i.e. the number of recently matriculated students. This outcome variable has been chosen in spirit of the matching function applied by the empirical literature on job-matching, in which new hires represent the job-matching outcome. For transferring the job matching function concept to student-university matching one-to-one, I would need to explain the number of first-year students by the number of applicants and the number of supplied university places. Unfortunately, no data on the number of applicants is available for the law schools which decentralized admission. Therefore, I use the number of first-year students as a first crude proxy for the matching efficiency and take the number of supplied university places into account for my second outcome variable.

The second outcome measure of the matching efficiency is the number of unassigned university places, i.e. the difference between the number of university places a university supplies and the number of first-year students. ${ }^{11}$ This second indicator allows a more detailed analysis with respect to the matching efficiency as it takes the supply side into account. The effect of the decentralization on this outcome is especially interesting as a high number of unassigned places has often been mentioned as a disadvantage of the less regulated decentralized admission procedure. It is also important to mention that the differences between the amount of supplied university places and the number of matriculated students can turn negative if the number of matriculated students exceeds the a priori fixed amount of university places to be supplied. This situation occurs for example if more students than expected accept a university's offer. ${ }^{12}$ Also, for this second outcome it would be desirable to account for the number of applicants in order to focus solely on the matching efficiency. As this data is unfortunately not available, the second measure of matching efficiency - the number of unassigned university places - can also be influenced by changing numbers of applicants. The measures of matching efficiency therefore may also comprise the attractiveness to apply for studies under the respective admission procedure.

The third outcome measure I consider is the drop-out rate within the first year of studies. It proxies the matching quality. As students who are allocated to a university that does not fit them - with respect to their preferences or ability - will face a higher risk of dropping out, the drop-out rate measures the consequences of the initial matching quality. The drop-out rate of university $i$ for the first-year students of year $t$ is calculated by dividing the number of second-year students at university $i$ in year $t+1$ by the number

\footnotetext{
${ }^{11}$ The numbers of supplied university places for the universities within the centralized admission procedure have been provided by the central clearinghouse. The according data for the law schools with decentralized admission has been inquired directly at all 16 federal state ministries of education and research. For the federal state of Bavaria, I had to contact each university directly as the state ministry could not provide the data.

${ }^{12}$ In fact, the number of matriculated students is regularly above the fixed number of university places within the centralized admission procedure (see Figure 3 in Section 5).
} 
of first-year students at university $i$ in year $t$. I restrict my analysis to the drop-outs after one year of studies as most drop-outs occur within the first year. Furthermore, by restricting my analysis to a one-year time lag, I lose only one year of observation (2008) for the drop-out analysis. Due to a missing panel identifier on an individual level, I am not able to construct the individual drop-out rate. The drop-out rate, as I define it, thus also captures the likelihood that a student completely cancels his studies as well as the likelihood that he changes subject or university within his first year of studies. Therefore, the drop-out rate is a measure of the universities' ability to retain its students. This approximation seems to be reasonable because changes between universities are not very common within the first year of studies.

For the differences-in-differences analysis, I apply two different samples. In order to compare law schools in (control) and outside of (treated) the federal state of North RhineWestphalia, I keep all German law schools (in and outside of North Rhine-Westphalia) in the first sample. All university departments of other subjects are dropped. The second sample consists of all law (treated) and medical (control) schools outside of North Rhine-Westphalia. Thus, I delete all departments of other subjects and all observations from within North Rhine-Westphalia. In both samples, I do not consider students at two private universities ${ }^{13}$ as they have never been part of the centralized admission process. Furthermore, I also restrict my analysis to the semesters starting in fall. Although university admission in general is possible twice a year - for the semester starting in spring and for the semester starting in fall - many universities only admit students in fall.

All three outcomes are measured on the university department level. Therefore, I aggregate the data by university departments. ${ }^{14}$ By aggregation, I obtain a panel data set of law and medical schools. Table 1 lists the number of law and medical schools in the sample for each year of the observation period. The table depicts the treated law schools and the two control groups separately. ${ }^{15}$ In general, my data contain all public law and medical programs existing in Germany. Only in two years few observations are missing due to non-reported data of two federal states.

Until 2003, 34 law schools existed outside of North Rhine-Westphalia. Data for one law school is missing in 1995 (University of Kiel) and for another one in 1997 (University of Hamburg). These two schools are missing because data on the federal state of SchleswigHolstein (1995) and Hamburg (1997) are not available. These missing observations are most likely missing at random as the federal states have not reported any data merely

\footnotetext{
${ }^{13}$ The University of Witten/Herdecke is the only private institution offering Medical Studies and the Bucerius Law School the only private school in the field of Law.

${ }^{14} \mathrm{An}$ analysis on the individual student level could also provide interesting insights e.g. with respect to the drop-out risk and the amount of human-capital acquisition. However, the current data protection law in Germany does not allow to follow individual students over time. Therefore, a panel identifier on the individual student level is not available for the data.

${ }^{15}$ For a more detailed list of all included law and medical schools see Table A.2 in the Appendix.
} 
Table 1: Number of Law and Medical Schools by Year (1995-2008)

\begin{tabular}{lrrrrrrr}
\hline & 1995 & 1996 & 1997 & 1998 & 1999 & 2000 & 2001 \\
\hline $\begin{array}{l}\text { Law Schools "treated" } \\
\text { (not in North Rhine-Westphalia) }\end{array}$ & 33 & 34 & 33 & 34 & 34 & 34 & 34 \\
$\begin{array}{l}\text { Law Schools "control 1" } \\
\text { (in North Rhine-Westphalia) }\end{array}$ & 6 & 6 & 6 & 6 & 6 & 6 & 6 \\
$\begin{array}{l}\text { Medical Schools "control 2" } \\
\text { (not in North Rhine-Westphalia) }\end{array}$ & 24 & 26 & 25 & 26 & 26 & 26 & 26 \\
\hline & 2002 & 2003 & 2004 & 2005 & 2006 & 2007 & 2008 \\
\hline $\begin{array}{l}\text { Law Schools "treated" } \\
\text { (not in North Rhine-Westphalia) }\end{array}$ & 34 & 34 & 33 & 33 & 33 & 33 & 32 \\
$\begin{array}{l}\text { Law Schools "control 1" } \\
\text { (in North Rhine-Westphalia) }\end{array}$ & 6 & 6 & 6 & 6 & 6 & 6 & 6 \\
$\begin{array}{l}\text { Medical Schools "control 2" } \\
\text { (not in North Rhine-Westphalia) }\end{array}$ & 26 & 26 & 26 & 26 & 26 & 26 & 26 \\
\hline
\end{tabular}

Data Source: Administrative Student Data (1995-2008), own calculations.

due to administrative problems. In 2004, the University of Dresden and, in 2008, the University of Rostock closed their law programs. Consequently, the number of treated law schools drops to 33 between 2004 and 2007 and to 32 in 2008.

Within North Rhine-Westphalia, six law schools exist over the entire observation period. Thus, although North Rhine-Westphalia is the largest German federal state, the first control group is rather small. Therefore, I also consider all medical schools outside of North Rhine-Westphalia as a second control group, which consists of 26 medical schools over the entire observation period. Data are only missing for two medical schools (University of Kiel and University of Lübeck) in 1995 and for one (University of Hamburg) in 1997. Again, the missing data is due to the unavailable data of the two federal states Schleswig-Holstein and Hamburg. ${ }^{16}$ The first sample that I use for the comparison between law schools in and outside of North Rhine-Westphalia, thus, consists of a total of 552 school-year observations. The second sample comprises the treated law schools and the control medical schools outside of North Rhine-Westphalia, which together amount to 829 school-year observations.

\footnotetext{
${ }^{16}$ Note also that the two medical schools in Munich (Technical University and Ludwig-Maximilian University) merged their programs already in 2000 and that Berlin merged its two programs (Free University and Humboldt University) in 2003. Therefore, I aggregate the number of students of both medical programs in Munich and in Berlin in all years. Furthermore, the University of Heidelberg offers two medical science programs, one combined with the University of Mannheim. Although students apply separately for both programs, matriculated students are not reported disaggregated in the administrative student data. Therefore, I consider both programs as one.
} 


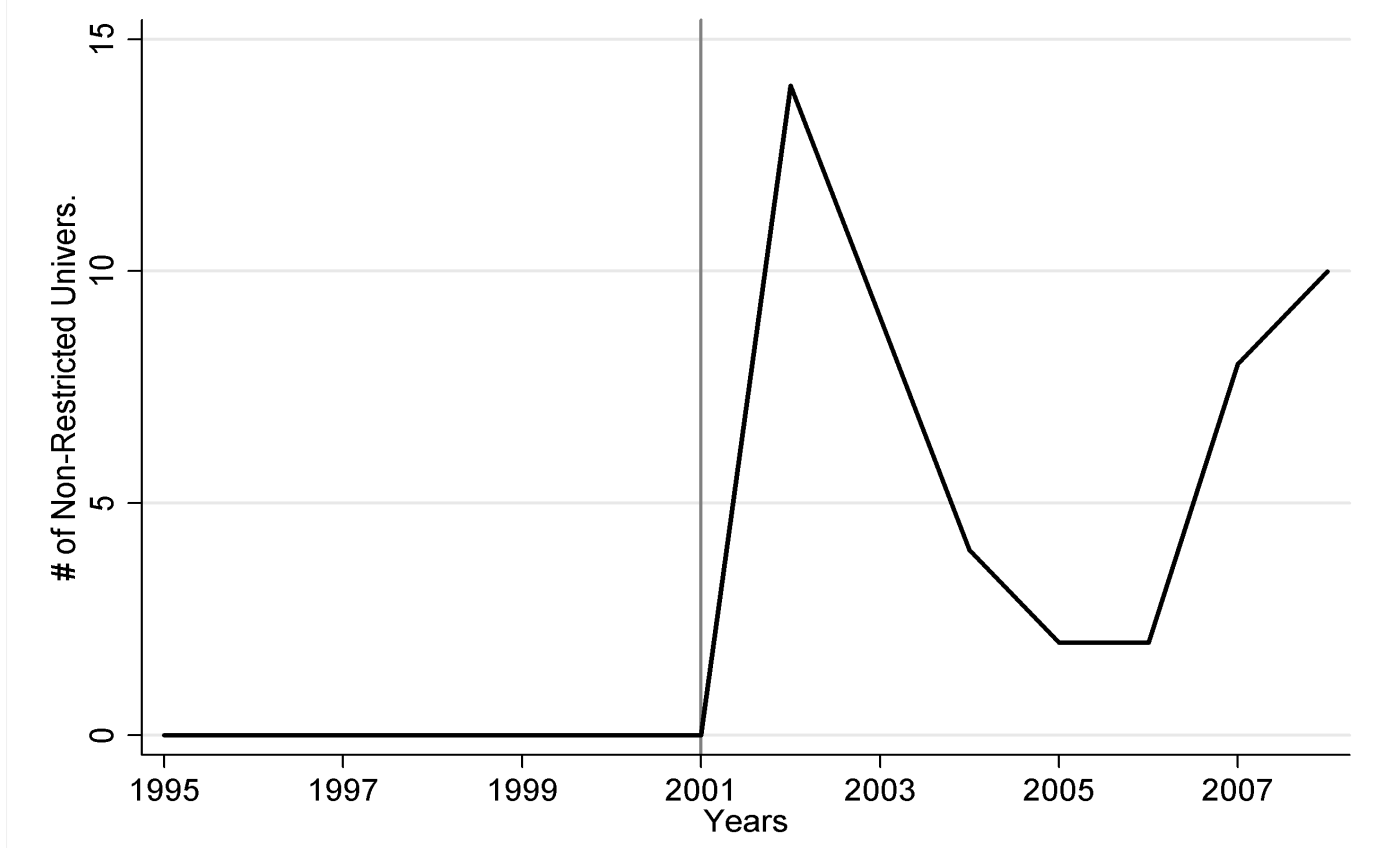

Data Source: Administrative Student Data (1995-2008), own calculations.

The panel of law and medical schools is not balanced over all years as data for two federal states are missing for one year each and as two universities closed their law programs. However, the number of law and medical schools in Germany overall has been very stable within the entire observation period. This ensures that the possibilities to study one of these two subjects (supply side) have not changed severely over time.

Despite the number of law and medical schools being very stable over time, admission restrictions in the field of law changed in the course of decentralizing admission. Figure 1 shows that, until 2002, all law schools had to fix the number of university places they were able to supply. ${ }^{17}$ After the decentralization, 14 law schools allowed prospective students to directly enroll into their program without any admission restrictions. This number dropped again to only two law schools with unrestricted admission in 2005 and 2006 and subsequently increased to nine and ten schools in 2007 and 2008. These frequent changes in admission restrictions directly after the decentralization, presumably, indicate that some law schools were experimenting to find a suitable admission procedure.

In order to distinguish the effect of abolishing all admission restrictions from abolishing the central coordination by the central clearinghouse, I estimate the decentralization effect also on a sample only consisting of universities that never (not in a single year) abolished

\footnotetext{
${ }^{17}$ However, for some unpopular universities these numbers in fact did not restrict admission because the universities - especially in the years prior to the decentralization - could not fill all supplied places (see Figure 3).
} 
their admission restrictions. This constraint in general reduces the number of treated law schools in the sample from 34 to 16 schools for which admission has always been restricted. As admission to the control law and medical schools has always been restricted within the centralized admission procedure, no observations of the control groups are dropped. As a consequence, the number of observations in the first sample, using the law schools in North Rhine-Westphalia as controls, drops from 552 observations to 301. The second sample, including the medical schools outside of North Rhine-Westphalia as controls, is reduced from 829 to 578 observations.

\section{Descriptive Evidence}

By depicting the development of the three different matching outcomes over time, I provide first descriptive evidence on whether the matching efficiency and the matching quality have changed in the course of decentralizing university admission. Furthermore, the descriptive analyses investigate whether the differences-in-differences assumption of common trends between treatment and control group applies. Therefore, Figures 2 - 4 depict the development over time for the number of first-year students, the number of unassigned university places, and the drop-out rate. ${ }^{18}$

Figure 2 compares the number of first-year students at the treated law schools outside of North Rhine-Westphalia with the law schools in North Rhine-Westphalia (first control group) and with the medical schools outside of North Rhine-Westphalia (second control group). Immediately after the decentralization of university admission, I observe a temporary increase in newly matriculated students from on average 300 students per university in 2001 to on average 350 students in 2002 and 2003 for the treated law schools. This sudden increase after the decentralization is even more remarkable as the number of first-year students has been constantly decreasing prior to the decentralization. After 2003, the numbers of first-year students, however, decreased again and reached a level of about nearly the same level as before the decentralization in 2001. If I restrict the sample to the treated law schools that never dropped their admission restrictions, I only observe a slight increase in first-year students for one year after the decentralization of admission. Thus, the temporary increase in first-year students at all treated law schools seems to be mainly driven by the schools which temporarily abolish all admission restrictions, i.e. which enable students to directly enroll into their law programs.

Comparing the two groups of treated law schools to the control law schools in North Rhine-Westphalia (left panel in Figure 2) does not indicate a change in the average number of first-year students at the control law schools in the year directly after the

\footnotetext{
${ }^{18}$ For a mean comparison of all three outcomes see also Table A.1 in the Appendix.
} 
Figure 2: Number of First-year Students over Time (1995-2008)

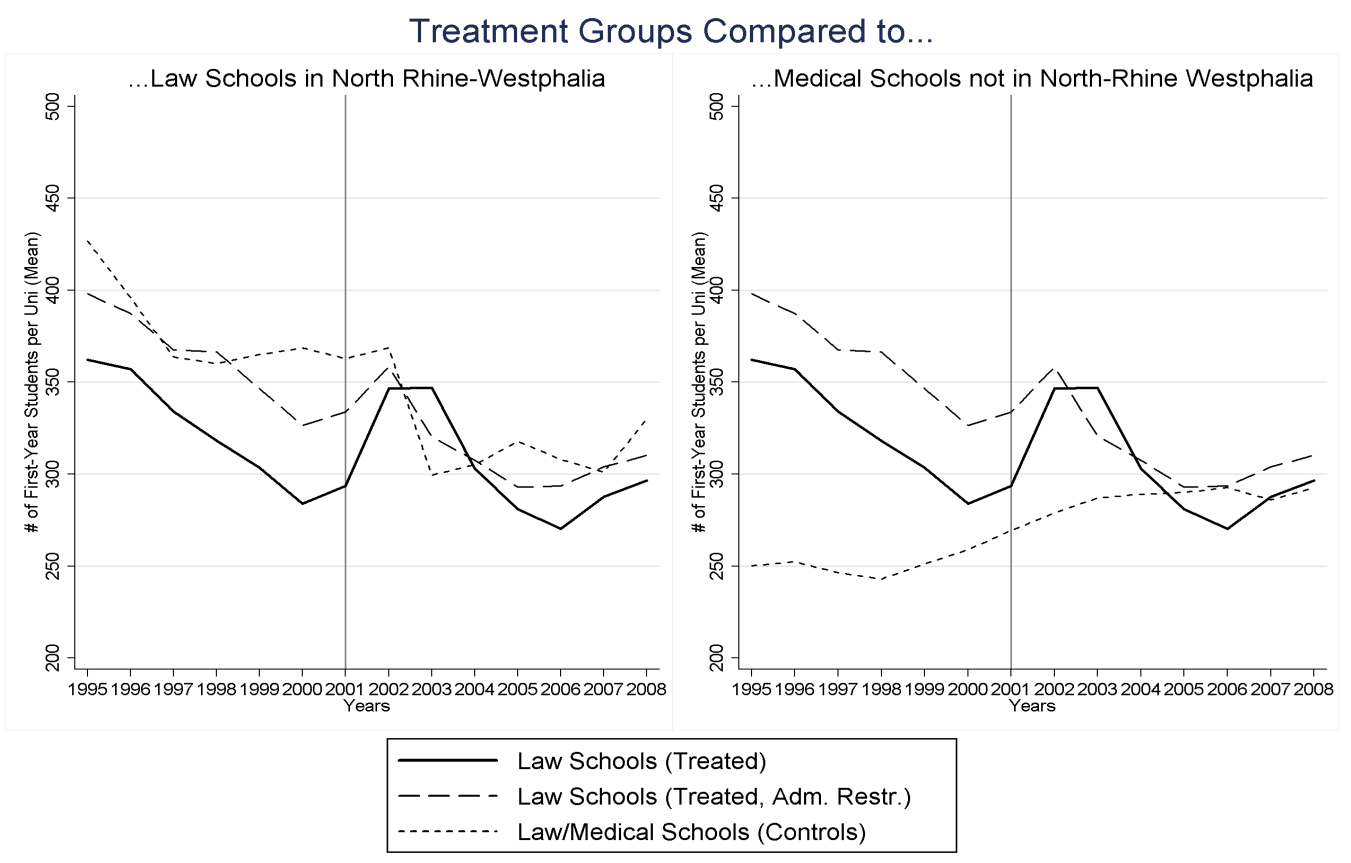

Data Source: Administrative Student Data (1995-2008), own calculations.

decentralization. After 2002 however, the number of newly matriculated students drops from above 350 students on average to about 300 students on average. This suggests that the composition of the control law schools might indeed be affected by the decentralization with a little time lag. The differences-in-differences assumption of common trends, however, is supported as the development of the treatment and control law schools over time is very similar prior to the reform in university admission. The comparison with the medical schools outside of North Rhine-Westphalia (right panel in Figure 2) shows that the number of first-year students within the second control group does not seem to be influenced by the decentralization process. The number of matriculated students at medical schools is constantly increasing to a moderate extent over the entire observation period. The development of the treatment and the second control group over time differ prior to the reform. Accounting for differing time trends, therefore, is more important for the comparison with the control medical schools.

As the development over time of the number of supplied university places is similar to the development of the number of first-year students (see Figure 3), a change in the number of first-year students after the decentralization could also be merely induced by adjustments in the supply of places. Therefore, Figure 3 depicts the difference between the number of university places and the number of first-year students per university, i.e. the number of unassigned university places, which is an important second outcome with respect to the matching efficiency. 
For both treatment groups (two panels at the top of Figure 3), the number of first-year students and the number of supplied university places diverge prior to the decentralization. Neither the number of supplied places nor the matching mechanism changed within this period. Therefore, this development is most likely driven by decreasing numbers of applications. This interpretation is even more likely as one argument for the decentralization of admission has been that the supply of places is not scarce anymore. The gap between the actually matriculated students and the supplied places is larger in the sample containing all treated law schools than in the restricted sample. Thus, I can infer that mainly the less demanded universities decided to drop all admission restrictions. After the decentralization, the average number of first-year students - as already shown in Figure 2 - increases instantaneously. In addition, the number of supplied places also increases in 2002, however, only to a very moderate extent. This development of the number of first-year students and supplied university places results in a decrease of unassigned university places. Within the sample of treated law schools applying admission restrictions in all years, the decrease in the number of unassigned places (as also the increase in matriculated students - see Figure 2) has been smaller than within the full sample of treated law schools. In the following years, the universities sometimes admitted more students than they had offered places, and sometimes places remained unassigned. Despite smaller gaps between the number of university places and the number of first-year students after the decentralization, it seems as if universities that were responsible for admission themselves were not able to allocate places very precisely.

Centralized admission to the control law and medical schools seems to yield a precise matching with a low level of unassigned places (see two panels at the bottom of Figure 3). In fact, the average number of first-year students is always above the a priori fixed number of supplied university places within both control groups. It seems as if the centralized procedure admits rather too many than too few prospective students. ${ }^{19}$ The centralized matching procedure, nevertheless, seems to be more precise compared to the decentralized admission as the difference between the supplied places and the newly matriculated students is basically constant over time. While the control medical schools do not seem to adjust their number of supplied places in course of the reform, the control law schools seem to adjust their supply similar to the treated law schools. This indicates again that the composition of the control group of law schools may not be independent of the reform process.

Descriptive evidence with respect to the drop-out rates exhibits no explicit influence of the decentralization process (Figure 4). Neither the treatment groups nor the control groups show major changes in drop-outs from 2002 onwards. Furthermore, the development

\footnotetext{
${ }^{19}$ As universities within the centralized admission process still directly admit foreign students, this could - at least to some degree - also induce the too high numbers of first-year students.
} 
Figure 3: Number of University Places and First-year Students over Time (1995-2008)
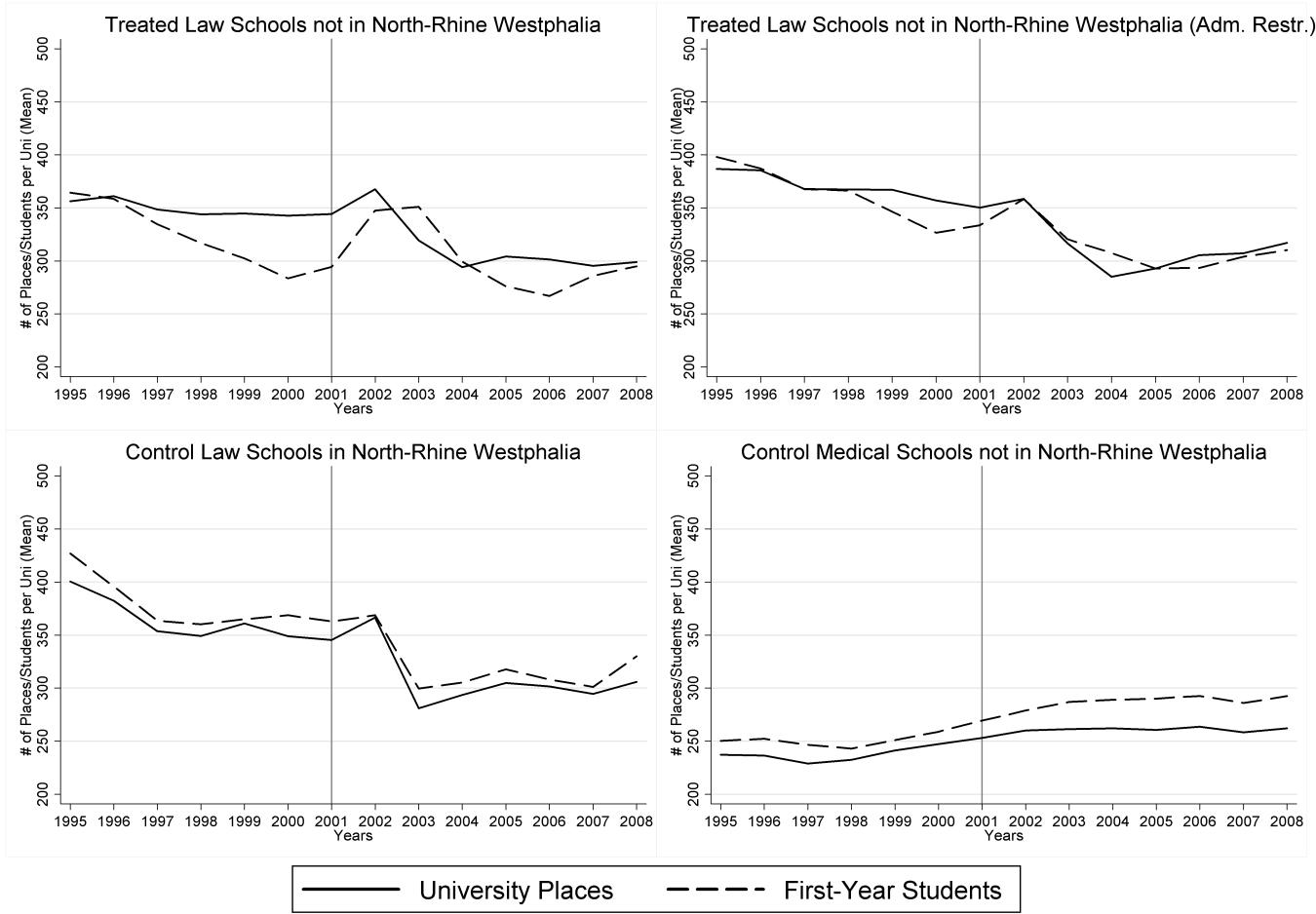

Data Source: Administrative Student Data (1995-2008), own calculations.

over time is fairly similar for both treatment groups, which suggests that abolishing all admission restrictions does not affect drop-out rates. Drop-outs at all treated law schools increase between 1995 and 2008 from about $10 \%$ on average to nearly $20 \%$ on average. The drop-out rate at the control law schools in North Rhine-Westphalia is lower compared to the other German law schools. ${ }^{20}$ Average drop-out rates at the control medical schools are also low (about 5\%) and hardly change over the entire observation period.

In order to compare the treated schools and control schools more precisely, I use differencesin-differences estimations. This multivariate approach also allows me to account for other factors that may influence my outcome variables.

\footnotetext{
${ }^{20}$ The average drop-out rate at the control law schools is fairly volatile. This is due to measuring the drop-out rate on the department rather than on the individual level and due to the small sample size of only six schools.
} 


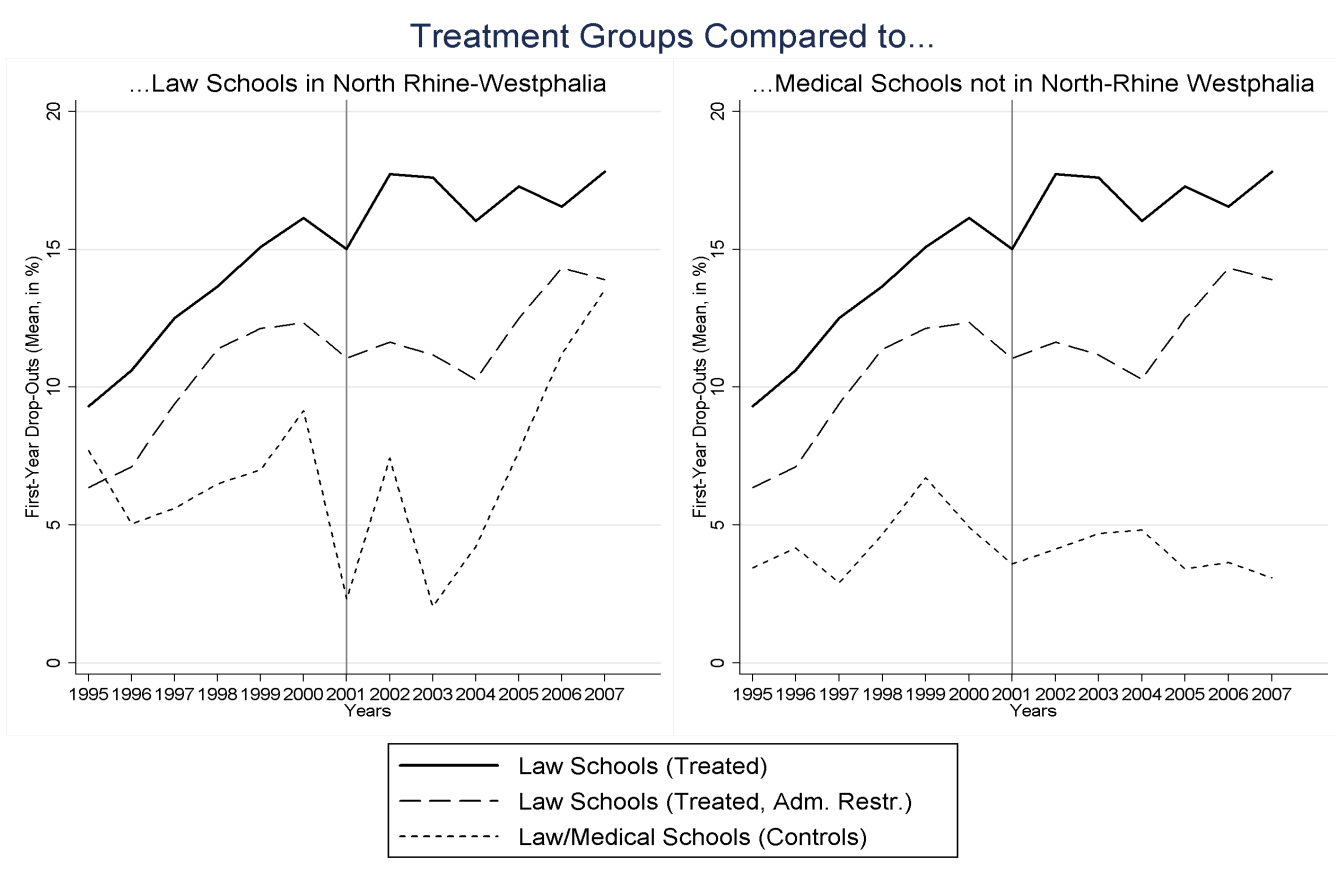

Data Source: Administrative Student Data (1995-2008), own calculations.

\section{Results}

The results of the differences-in-differences estimations are presented separately for the three outcomes (i) the number of first-year students, (ii) the number of unassigned university places, and (iii) the drop-out rate. I estimate different Ordinary Least Squares (OLS) models using both control groups - the law schools located in North Rhine-Westphalia and the medical schools outside of North Rhine-Westphalia. The presented models are a standard OLS regression (OLS), an OLS school fixed effect model (OLS FE I) and an OLS school fixed effect estimation using a sample that is restricted to the treated law schools that have never abolished their admission restrictions (OLS FE II).

\subsection{Number of First-Year Students}

Table 2 presents the results with respect to the number of first-year students when using the law schools of North Rhine-Westphalia as controls. The classical differencesin-differences estimates in the first column indicate a weakly significant increase in the number of first-year students after the decentralization of admission. After the reform, on average 42 more students matriculated at the treated law schools. The control variables account for significantly less matriculated students at the law schools outside of North Rhine-Westphalia and significantly less students at all law schools from 2002 onwards. 
Table 2: The Effect of Decentralized Admission on the Number of First-Year Students (Controls: Law Schools in North Rhine-Westphalia)

\begin{tabular}{|c|c|c|c|c|c|}
\hline & OLS & OLS & OLS & OLS FE I & OLS FE II \\
\hline Law Treated $\times$ After & $\begin{array}{c}42.39^{*} \\
(25.25)\end{array}$ & $\begin{array}{r}31.16 \\
(25.43)\end{array}$ & $\begin{array}{c}88.79^{*} \\
(49.32)\end{array}$ & $\begin{array}{l}85.67^{* *} \\
(22.78)\end{array}$ & $\begin{array}{r}35.48 \\
(25.48)\end{array}$ \\
\hline Law Treated & $\begin{array}{l}-56.05^{* * *} \\
(17.84)\end{array}$ & $\begin{array}{l}-56.05^{* * *} \\
(17.70)\end{array}$ & $\begin{array}{l}-27.23 \\
(30.25)\end{array}$ & - & - \\
\hline After & $\begin{array}{l}-58.95^{* *} \\
(23.25)\end{array}$ & $\begin{array}{l}-45.31^{*} \\
(24.09)\end{array}$ & $\begin{array}{r}-13.24 \\
(45.72)\end{array}$ & $\begin{array}{r}-13.74 \\
(17.03)\end{array}$ & $\begin{array}{r}-8.66 \\
(17.27)\end{array}$ \\
\hline \multicolumn{6}{|l|}{ Covariates } \\
\hline Tuition Fees & & $\begin{array}{l}-31.84^{* *} \\
(16.17)\end{array}$ & $\begin{array}{r}6.60 \\
(17.66)\end{array}$ & $\begin{array}{r}2.68 \\
(10.28)\end{array}$ & $\begin{array}{r}18.48 \\
(11.33)\end{array}$ \\
\hline Excellence Labels & & $\begin{array}{l}134.66^{* * *} \\
(45.03)\end{array}$ & $\begin{array}{l}227.02^{* * *} \\
(44.20)\end{array}$ & $\begin{array}{r}47.42 \\
(29.13)\end{array}$ & $\begin{array}{c}52.22^{*} \\
(28.64)\end{array}$ \\
\hline \multicolumn{6}{|l|}{ Time Trends } \\
\hline Law Treated $\times$ Year & & & $\begin{array}{l}-13.93^{* * *} \\
(2.58)\end{array}$ & $\begin{array}{l}-13.00^{* * *} \\
(2.19)\end{array}$ & $\begin{array}{l}-11.87^{* * *} \\
(2.80)\end{array}$ \\
\hline Law Control $\times$ Year & & & $\begin{array}{r}-6.79 \\
(5.94)\end{array}$ & $\begin{array}{r}-6.62 \\
(4.00)\end{array}$ & $\begin{array}{l}-8.32^{*} \\
(4.15)\end{array}$ \\
\hline$N$ & 552 & 552 & 552 & 552 & 301 \\
\hline$R^{2}$ & 0.0298 & 0.0483 & 0.0972 & 0.1571 & 0.3101 \\
\hline
\end{tabular}

Data Source: Administrative Student Data (1995-2008), own calculations; clustered standard errors in parentheses; $* / * * / * *$ indicate significance at the $10 / 5 / 1$ percent level.

Controlling for additional covariates and treatment- and control-specific time trends (column 3) increases the treatment effect to about 89 students per treated law school. The estimate of interest remains weakly significant. The significance of the other covariates, however, mainly disappears when I control for differing time trends. The treated law schools show a significantly negative time trend prior to the reform, while the slightly negative time trend for the control law schools is not significant. Estimating the same specification in an OLS school fixed effect setting (OLS FE I) does not change the estimates remarkably. I find a significant increase in matriculation by about 86 students when accounting for the negative time trend at the treated law schools.

The decentralization of university admission, however, has no significant effect on the number of first-year students if I restrict the sample to the law schools that have always - also after the reform - applied admission restrictions. This suggests that the estimated increase in matriculated students is mainly driven by law schools enabling students to directly enroll into their program. It is likely that prospective students are attracted to studying law at the schools which dropped admission restrictions by the possibility to directly enroll into their law program. This is especially likely for applicants who prefer to stay at their local university as they are guaranteed a place by enrolling directly. 
Table 3: The Effect of Decentralized Admission on the Number of First-Year Students (Controls: Medical Schools not in North Rhine-Westphalia)

\begin{tabular}{|c|c|c|c|c|c|}
\hline & OLS & OLS & OLS & OLS FE I & OLS FE II \\
\hline Law Treated $\times$ After & $\begin{array}{l}-51.45^{* * *} \\
(16.62)\end{array}$ & $\begin{array}{l}-49.70^{* * *} \\
(16.26)\end{array}$ & $\begin{array}{r}46.18 \\
(32.16)\end{array}$ & $\begin{array}{l}49.70^{* *} \\
(19.05)\end{array}$ & $\begin{array}{r}2.65 \\
(21.72)\end{array}$ \\
\hline Law Treated & $\begin{array}{l}68.38^{* * *} \\
(11.76)\end{array}$ & $\begin{array}{l}68.38^{* * *} \\
(11.50)\end{array}$ & $\begin{array}{l}123.91^{* * *} \\
(19.73)\end{array}$ & - & - \\
\hline After & $\begin{array}{l}34.89^{* * *} \\
(12.49)\end{array}$ & $\begin{array}{l}30.93^{* *} \\
(12.50)\end{array}$ & $\begin{array}{r}32.72 \\
(24.41)\end{array}$ & $\begin{array}{c}24.67^{*} \\
(12.61)\end{array}$ & $\begin{array}{l}27.12^{* *} \\
(12.82)\end{array}$ \\
\hline \multicolumn{6}{|l|}{ Covariates } \\
\hline Tuition Fees & & $\begin{array}{r}-18.92 \\
(15.49)\end{array}$ & $\begin{array}{r}6.60 \\
(16.44)\end{array}$ & $\begin{array}{r}8.10 \\
(12.12)\end{array}$ & $\begin{array}{r}20.13 \\
(15.28)\end{array}$ \\
\hline Excellence Labels & & $\begin{array}{l}221.02^{* * *} \\
(35.57)\end{array}$ & $\begin{array}{l}227.02^{* * *} \\
(35.10)\end{array}$ & $\begin{array}{r}82.34 \\
(59.30)\end{array}$ & $\begin{array}{r}83.42 \\
(59.88)\end{array}$ \\
\hline \multicolumn{6}{|l|}{ Time Trends } \\
\hline Law Treated $\times$ Year & & & $\begin{array}{l}-14.76^{* * *} \\
(2.79)\end{array}$ & $\begin{array}{l}-13.61^{* * *} \\
(2.19)\end{array}$ & $\begin{array}{l}-12.60^{* * *} \\
(2.92)\end{array}$ \\
\hline Medicine $\times$ Year & & & $\begin{array}{r}-.93 \\
(3.14)\end{array}$ & $\begin{array}{r}.93 \\
(2.35)\end{array}$ & $\begin{array}{r}.27 \\
(2.43)\end{array}$ \\
\hline$N$ & 829 & 829 & 829 & 829 & 578 \\
\hline$R^{2}$ & 0.0422 & 0.0855 & 0.1157 & 0.1232 & 0.1647 \\
\hline
\end{tabular}

Data Source: Administrative Student Data (1995-2008), own calculations; clustered standard errors in parentheses; $* * * / * * *$ indicate significance at the $10 / 5 / 1$ percent level.

Estimating the differences-in-differences models with the medical schools outside of North Rhine-Westphalia as controls yields similar results (see Table 3). The OLS fixed effect model (OLS FE I) suggests a significant increase by about 50 students after admission has been decentralized. Again, this effect does not persist if I restrict the sample to the law schools for which admission has always been restricted. The effect of interest is negative in the classical differences-in-differences approach but changes in sign when I add the subject-specific time trends. As I observe different time trends for law and medical schools in the number of first-year students (see Figure 2), accounting for different time trends is particularly important for the estimations using this second control group.

\subsection{Number of Unassigned University Places}

Another outcome measuring the matching efficiency is the number of unassigned university places. The advantage of this outcome is that it accounts for changes in the number of supplied university places and thus can show whether the increase in newly matriculated students merely reflects the increasing supply of university places. The estimation results for this outcome are presented in Table 4. Using the final specification of Tables 
Table 4: The Effect of Decentralized Admission on the Number of Unassigned University Places

\begin{tabular}{|c|c|c|c|}
\hline & OLS & OLS FE I & OLS FE II \\
\hline \multicolumn{4}{|c|}{ Control Group: Law Schools in North Rhine-Westphalia } \\
\hline Law Treated $\times$ After & $\begin{array}{l}-63.00^{* *} \\
(25.66)\end{array}$ & $\begin{array}{l}-52.09^{* * *} \\
(17.40)\end{array}$ & $\begin{array}{r}-35.65 \\
(24.20)\end{array}$ \\
\hline Law Treated & $\begin{array}{r}9.01 \\
(15.69)\end{array}$ & - & - \\
\hline After & $\begin{array}{r}1.57 \\
(23.41)\end{array}$ & $\begin{array}{l}2.11^{* * *} \\
(7.75)\end{array}$ & $\begin{array}{r}1.83 \\
(7.74)\end{array}$ \\
\hline$N$ & 496 & 496 & 301 \\
\hline$R^{2}$ & 0.1343 & 0.1194 & 0.0629 \\
\hline
\end{tabular}

Control Group: Medical Schools not in North Rhine-Westphalia

\begin{tabular}{lccc} 
Law Treated $\times$ After & $-47.98^{* * *}$ & $-37.95^{* *}$ & -23.11 \\
& $(14.28)$ & $(16.46)$ & $(23.33)$ \\
Law Treated & 6.90 & - & - \\
\multirow{2}{*}{ After } & $(8.62)$ & & \\
& -14.88 & $-13.05^{* * *}$ & $-13.02^{* * *}$ \\
\hline$N$ & $(10.37)$ & $(4.71)$ & $(4.66)$ \\
$R^{2}$ & 773 & 773 & 578 \\
\hline
\end{tabular}

Data Source: Administrative Student Data (1995-2008), own calculations; clustered standard errors in parentheses; * $/ * * / * * *$ indicate significance at the 10/5/1 percent level; additional covariates: tuition fees, excellence labels, treatment- and control-specific time trends.

2 and 3, I find that the number of unassigned places at treated law schools decreased after the change towards a decentralized admission. Employing the law schools within North Rhine-Westphalia (the medical schools not in North Rhine-Westphalia) as a control group, yields an estimate of on average 63 (48) less unassigned places per university in the OLS model. However, I once again only observe this decrease in the number of unassigned places in the sample including all treated law schools. For the law schools that restricted admission also after the decentralization, the estimations do not reveal a significant influence of the change in admission procedures.

Hence, taking the number of supplied university places into account shows that the increase in first-year students exceeds the increase in supplied university places. The resulting reduction of unassigned places is, as the increase in first-year students, mainly driven by abolishing admission restrictions. Therefore, my results with respect to the first and second matching outcome suggest that the matching efficiency improved after 
the decentralization by enabling less demanded universities to directly enroll prospective students without any admission selection. Note, however, that the underlying increase in first-year students could also be driven by an increase in applicants. Due to a lack of data, I cannot control for changes in the number of applicants. Thus, my measures of the matching efficiency also encompass changes in the attractiveness to apply before and after the decentralization.

\subsection{Drop-Out Rate}

Estimating the influence of the decentralization process on the drop-out rate is especially interesting as the drop-out rate is an outcome with practical relevance, which is difficult to assess in a theoretical framework. As some law schools had to drop all admission restrictions in order to attract more students, the composition of the student body could be affected. For example, students could be less suited for the subject of law studies or for the respective university because students' ability to pursue studies is not assessed a priori by any admission criteria. Consequently, an increase in drop-out rates could be expected. Whether the empirical data supports this hypothesis is explored by my estimations with respect to the drop-out rate. The estimation results are displayed in Table 5 .

All specifications using both control groups show no significant effect of decentralizing admission. However, the treatment effect is positive in the estimations on the full sample of treated law schools (OLS, OLS FE I) and negative in the estimations on the restricted sample of law schools that keep their admission restrictions (OLS FE II). Despite all treatment effects being insignificant, this seems to support the above stated hypothesis that lower admission restrictions could attract students with a higher drop-out probability. 
Table 5: The Effect of Decentralized Admission on Drop-Out Rates

\begin{tabular}{|c|c|c|c|}
\hline & OLS & OLS FE I & OLS FE II \\
\hline \multicolumn{4}{|c|}{ Control Group: Law Schools in North Rhine-Westphalia } \\
\hline Law Treated $\times$ After & $\begin{array}{r}1.73 \\
(4.30)\end{array}$ & $\begin{array}{r}1.63 \\
(4.59)\end{array}$ & $\begin{array}{r}-1.39 \\
(4.64)\end{array}$ \\
\hline Law Treated & $\begin{array}{c}6.63^{* *} \\
(2.74)\end{array}$ & - & - \\
\hline After & $\begin{array}{r}-2.14 \\
(3.98)\end{array}$ & $\begin{array}{r}-1.97 \\
(4.32)\end{array}$ & $\begin{array}{r}-1.37 \\
(4.24)\end{array}$ \\
\hline$N$ & 513 & 513 & 279 \\
\hline$R^{2}$ & 0.1526 & 0.1244 & 0.0959 \\
\hline
\end{tabular}

Control Group: Medical Schools not in North Rhine-Westphalia

\begin{tabular}{lccc} 
Law Treated $\times$ After & .21 & .10 & -2.58 \\
& $(2.95)$ & $(3.40)$ & $(3.42)$ \\
Law Treated & $6.27^{* * *}$ & - & - \\
\multirow{2}{*}{ After } & $(1.89)$ & & \\
& -.65 & -.30 & -.05 \\
& $(2.23)$ & $(3.39)$ & $(3.47)$ \\
\hline$N$ & 769 & 769 & 535 \\
$R^{2}$ & 0.2391 & 0.0578 & 0.0328 \\
\hline
\end{tabular}

Data Source: Administrative Student Data (1995-2008), own calculations; clustered standard errors in parentheses; * $/ * * / * * *$ indicate significance at the $10 / 5 / 1$ percent level; additional covariates: tuition fees, excellence labels, treatment- and control-specific time trends.

\section{Conclusion}

This paper set out to examine a natural experiment in university admission. Using a differences-in-differences approach, I estimate the effect of decentralizing admission to German law schools (outside the federal state of North Rhine-Westphalia) on the efficiency and the quality of the resulting student-university matching. My estimation strategy employs two different control groups for which admission has been centrally administered over the entire observation period. The first group are the law schools within North Rhine-Westphalia, and the second are the medical schools outside of North RhineWestphalia. Moreover, the administrative student data on all students within Germany allow me to measure the effect with respect to three different outcomes: (i) the number of first-year students, (ii) the number of unassigned university places, (iii) the dropout rate. My quantitative evaluation complements the prominent theoretical literature 
on college admission and its matching efficiency. The advantage of evaluation studies, in this context, is that they can also quantify how prevalent (theoretically identified) inefficiencies are in practice.

My results show that the number of first-year students on average increased and that the number of unassigned places on average decreased at the law schools which decentralized admission. This increase in the matching efficiency is mainly driven by law schools abolishing all admission restrictions, which enabled students to enroll into a law program without any application process. In fact, my estimations show no significant effect of the decentralization for the highly demanded schools which always restricted admission. However, the decentralization has positive effects with respect to the matching efficiency for the less demanded schools because they can adjust or completely abolish their admission restrictions. As the matching efficiency increases by lowering admission restrictions, the decentralization of admission could also be associated with a decreasing matching quality assessed by the drop-out rate. My results show no significant effects in this dimension but hint at higher drop-out rates for universities softening admission restrictions.

The improved matching efficiency after the decentralization is based on an increase in matriculated students. This increase may also be driven by changes in the number of applicants before and after the decentralization process. As no data on the number of applicants is available for the law schools which decentralized admission, I cannot control for changes in the number of applicants. Therefore, my outcomes with respect to the matching efficiency might also capture the difference in the attractiveness to apply before and after the reform. In order to evaluate merely the matching mechanism, it would be necessary to take the number of applicants into account. If this data were available, an estimation strategy corresponding to the empirical job matching literature could be a possible path to proceed. The matching function for student-university matching would need to describe how the stock of applicants and supplied university places translate into the matching outcome of newly matriculated students.

In this regard, I believe that my study is only a first attempt to evaluate a reform in university admission with respect to its matching outcomes in practice. Further research exploiting other natural experiments in university admission is highly desirable. For example, a comparison of a theoretically more efficient centralized system with a decentralized system is interesting empirical work for future research. Moreover, also changes within centralized admission procedures are important to evaluate in order to improve our knowledge on optimal matching procedures. Assessing the differences in real-life outcomes between the centralized student- and college-optimal matching algorithm could be very promising as both procedures are efficient from a theoretical perspective. Such an emerging empirical literature exploiting natural experiments in the admission process 
could take on an important role in assessing how different admission procedures affect the student-university matching in practice and, consequently, in designing better matching procedures.

Considering the theoretical knowledge on the optimality of different matching algorithms, it is surprising how diverse admission procedures are organized all over the world. At present, several countries are discussing to reform their centralized admission procedure. German politicians and practitioners, for instance, have been discussing a new university admission procedure for several years now. Furthermore, the central authority 'UCAS' administering admissions in the UK initiated the "Admissions Process Review" that is supposed to "map future models of admissions that could deliver improved efficiencies" (UCAS; 2011). Within this transformation process, evaluating already existing admission procedures could be an important factor. 


\section{References}

Abdulkadiroglu, A. and Sönmez, T. (2003). School Choice: A Mechanism Design Approach, The American Economic Review 93(3): 729-747.

Ajayi, K. F. (2011). School Coice and Educational Mobility: Lessons from Secondary School Applications in Ghana, Unpublished Working Paper.

Alcalde, J. and Romero-Medina, A. (2005). Sequential decisions in the college admissions problem, Economis Letters 86: 153-158.

Braun, S., Dwenger, N. and Kübler, D. (2010). Telling the Truth May Not Pay Off: An Empirical Study of Centralised University Admissions in Germany, The B.E. Journal of Economic Analysis \& Policy 10(1): 21.

Dwenger, N., Storck, J. and Wrohlich, K. (2012). Do Tuition Fees Affect the Mobility of University Applicants? Evidence from a Natural Experiment, Economics of Education Review 31(1): 155-167.

Fahr, R. and Sunde, U. (2009). Did the Hartz Reforms Speed-Up the Matching Process? A Macro-Evaluation Using Empirical Matching Functions, German Economic Review 10(3): 284-316.

Gale, D. and Shapley, L. S. (1962). College Admissions and the Stability of Marriage, The American Mathematical Monthly 69(1): 9-15.

Haeringer, G. and Wooders, M. (2011). Incentives in Decentralized Random Matching Markets, International Journal of Game Theory 40: 1-28.

Hübner, M. (2009). Do Tuition Fees Affect Enrollment Behavior? Evidence from a 'Natural Experiment' in Germany, Discussion Paper No. 69, CDSE University of Mannheim.

Horstschräer, J. (2011). University Rankings in Action? The Importance of Rankings and an Excellence Competition for University Choice of High-Ability Students, ZEW Discussion Paper 11-061, Mannheim.

Horstschräer, J. and Sprietsma, M. (2010). The Effects of the Bologna Process on College Enrollment and Drop-out Rates, ZEW Discussion Paper No. 10-018, Mannheim.

Kagel, J. H. and Roth, A. E. (2000). The Dynamies of Rcorganization in Matching Markets: A Laboratory Experiment Motivated by a Natural Experiment, The Quarterly Journal of Economics 115: 201-235.

Kara, T. and Sönmez, T. (1997). Implementation of College Admission Rules, Economic Theory 9: 197-218. 
Kelso, A. S. and Crawford, V. P. (1982). Job matching, coalition formation, and gross substitutes, Econometrica 50: 1483-1504.

Klaus, B. and Klijn, F. (2006). Median stable matching for college admissions, Internationa Journal of Game Theory 34: 1-11.

Krishna, A. and Ünver, M. U. (2008). Improving the Efficiency of Course Bidding at Business Schools: Field and Laboratory Studies, Marketing Science 27(2): 262-282.

Müller, C. (2007). Mehrfachbewerbung - Ist eine Dezentrale Studienplatzvergabe verteilungsoptimal, effizient und kosten günstig?, Duckner \& Humboldt, Berlin.

Müller, C. (2009). Mehrfachbewerbung, Jahrbücher für Nationalökonomie und Statistik 229(5): 544-569.

Pais, J. (2008a). Incentives in Decentralized Random Matching Markets, Games and Economic Behavior 64: 632-649.

Pais, J. (2008b). Random Matching in the College Admissions Problem, Economic Theory 35: $99-116$.

Petrongoli, B. and Pissarides, C. A. (2001). Looking into the Black Box: A Survey of the Matching Function, Journal of Economic Literature 39(2): 390-431.

Pissarides, C. A. (2011). Equilibrium in the Labor Market with Search Frictions, American Economic Review 101(4): 1092-1105.

Portela, M., Areal, N., Sá, C., Alexandre, F., Cerejeira, J., Carvalho, A. and Rodrigues, A. (2008). Evaluating Student Allocation in the Portuguese Public Higher Education System, Higher Education 56: 185-203.

Roth, A. E. (1984a). Stability and Polarization of Interests in Job Matching, Econometrica 52: $47-57$.

Roth, A. E. (1984b). The Evolution of the Labor Market for Medical Interns and Residents: A Case Study in Game Theory, Journal of Political Economy 92(6): 991-1016.

Roth, A. E. (1985). The College Admissions Problem is not Equivalent to the Marriage Problem, Journal of Economic Theory 36: 277-288.

Roth, A. E. (1991). A Natural Experiment in the Organization of Entry-Level Labor Markets: Regional Markets for New Physicians and Surgeons in the United Kingdom, The American Economic Review 81(3): 415-440.

Roth, A. E. (2002). The Economist as Engineer: Game Theory, Experimental Economics and Computation as Tools of Design Economics, Econometrica 70(4): 1341-1378. 
Roth, A. E. and Peranson (1999). The Redesign of the Matching Market for American Physicians: Some Engineering Aspects of Economic Design, The American Economic Review 89(4): 748-780.

Roth, A. E. and Sotomayor, M. (1989). The College Admission Problem Revisited, Econometrica 57(3): 559-570.

Roth, A. E. and Sotomayor, M. (1992). Two-Sided Matching, Handbook of Game Theory 1: $485-541$.

Roth, A. E. and Vate, J. H. V. (1990). Random Paths to Stability in Two-Sided Matching, Econometrica 58(6): 1475-1480.

Roth, A. E. and Vate, J. H. V. (1991). Incentives in Two-Sided Matching with Random Stable Mechanisms, Economic Theory 1: 31-44.

Roth, A. E. and Xing, X. (1994). Jumping the Gun: Imperfections and Institutions Related to the Timing of Market Transactions, The American Economic Review 84(4): 3144 .

UCAS (2011). http://www.ucas.com/reviews/admissionsprocessreview [last acessed on 2011-10-17], Universities and Colleges Admission Service.

Weiler, W. (2009). On the Problem of Finding a Suitable Distribution of Students to Universities in Germany, Physica A 388: 4475-4483.

Westkamp, A. (2010). An Analysis of the German University Admissions System, Working Paper, University of Bonn.

ZVS (2000). ZVSinfo - Wintersemester 2000/2001, Zentralstelle für die Vergabe von Studienplätzen, Dortmund. 


\section{A Appendix}

Table A.1: Mean Statistics of First-year Students, Unassigned University Places and Drop-out Rates

\begin{tabular}{|c|c|c|c|c|}
\hline & \multicolumn{2}{|c|}{ Before Decentralization } & \multicolumn{2}{|c|}{ After Decentralization } \\
\hline & Mean & Std. Dev. & Mean & Std. Dev. \\
\hline & \multicolumn{4}{|c|}{ Treated Law Schools not in North Rhine-Westphalia } \\
\hline First-year Students & 321.5 & 105.0 & 305.0 & 113.1 \\
\hline Unassigned Places & 26.9 & 62.0 & 22.24 & 54.7 \\
\hline \multirow[t]{2}{*}{ Drop-out Rate } & 13.2 & 7.9 & 17.2 & 8.9 \\
\hline & \multicolumn{4}{|c|}{ Treated Law Schools not in North Rhine-Westphalia (Adm. Restr.) } \\
\hline First-year Students & 360.5 & 117.2 & 313.0 & 115.6 \\
\hline Unassigned Places & 8.3 & 50.6 & 4.8 & 38.8 \\
\hline \multirow[t]{2}{*}{ Drop-out Rate } & 10.0 & 8.3 & 12.3 & 8.0 \\
\hline & \multicolumn{4}{|c|}{ Control Law Schools in North Rhine-Westphalia } \\
\hline First-year Students & 377.6 & 107.3 & 318.6 & 69.4 \\
\hline Unassigned Places & -14.5 & 23.0 & -11.8 & 28.2 \\
\hline \multirow[t]{2}{*}{ Drop-out Rate } & 6.2 & 8.9 & 7.7 & 12.4 \\
\hline & \multicolumn{4}{|c|}{ Control Medicine Schools not in North Rhine-Westphalia } \\
\hline First-year Students & 253.1 & 104.7 & 288.0 & 150.6 \\
\hline Unassigned Places & -13.6 & 26.9 & -26.9 & 48.2 \\
\hline Drop-out Rate & 4.4 & 15.1 & 4.0 & 7.4 \\
\hline
\end{tabular}

Data Source: Administrative Student Data (1995-2008), own calculations. 
Table A.2: Universities Offering Law and/or Medical Studies in or Outside of North Rhine-Westphalia

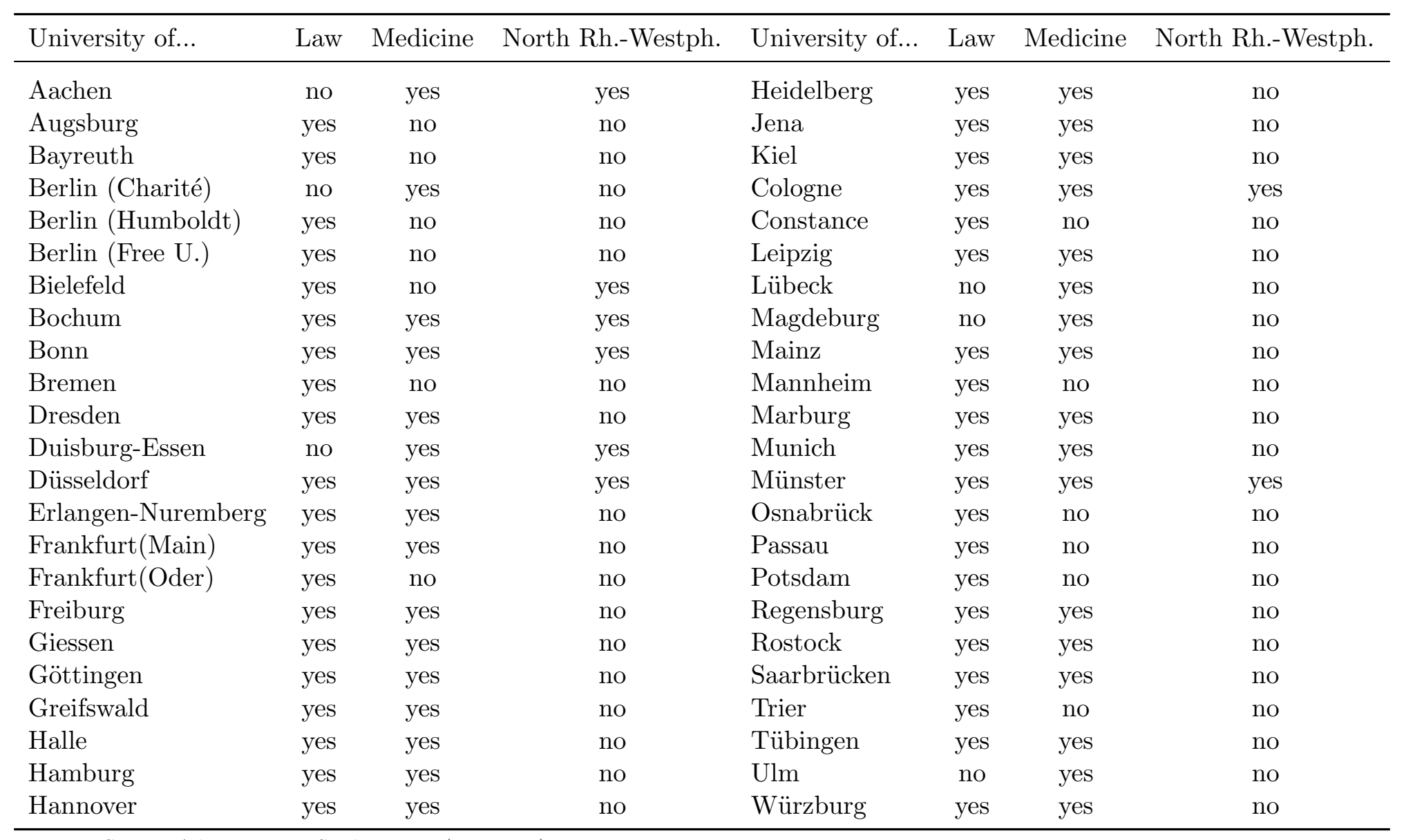

Data Source: Administrative Student Data (1995-2008). 